\title{
Acceleration of Echinacea purpurea (L.) Moench Shoot Growth by Benzyl Adenine and Indole Butyric Acid Addition
}

DOI: $10.18196 / p t .2019 .101 .117-124$

\author{
Nur Rahmawati Wijaya* and Heru Sudrajad \\ Center for Research and Development of Medicinal Plants and Traditional Medicines, Tawangmangu, \\ Jalan Raya Lawu No. 11 Tawangmangu, Karanganyar, Central Java 57792, Indonesia \\ *Corresponding author, email: n.rahmawatiwijaya@gmail.com
}

\begin{abstract}
Echinacea (Echinacea purpurea (L.) Moench) is a medicinal plant known to boost the immune system. Propagation is necessary to increase production. One of the methods of propagation in tissue culture. This research was conducted to understand the most suitable concentration of plant growth regulators. The treatment was given a combination of Benzyl Adenine (BA) and Indole Butyric Acid (IBA) with BA concentration of 1 ppm, 2 ppm, 3 ppm and 4 ppm while the IBA concentration used was 1 ppm and 2 ppm. The next step was subculture by using the combination among IBA 0 ppm, 0.5 ppm, 0.75 ppm and BAP O ppm, 0.5 ppm, 0.75 ppm of BAP. The result showed that the most shoots produced by the combination treatment of BA 2 ppm and IBA 1 ppm while the highest shoot and leaf number is best produced in treatment BA 1 ppm and IBA 2 ppm. The largest number of shoots was shown by treatment BA 2 ppm and IBA 1 ppm. This study can be concluded that BA 1 ppm and IBA 2 ppm, and BA 2 ppm and IBA 1 ppm gave the best treatment for shoot growth and control for root induction.
\end{abstract}

Keywords: Echinacea purpurea, Echinacea, Benzyl Adenine, Indole Butyric Acid, Callus

\section{ABSTRAK}

Ekinase (Echinacea purpurea (L.) Moench) merupakan tumbuhan obat yang dikenal berkhasiat meningkatkan kekebalan tubuh. Peningkatkan produksi Ekinase sangat penting dilakukan yaitu dengan perbanyakan, salah satunya dengan kultur jaringan. Tujuan dari penelitian ini adalah untuk mengetahui konsentrasi zat pengatur tumbuh (ZPT) yang paling sesuai untuk pertumbuhan Ekinase. Perlakuan ZPT yang diberikan berupa kombinasi Benzil Adenin (BA) dan Indole Butyric Acid (IBA) dengan konsentrasi BA 1 ppm, 2 ppm, 3 ppm dan 4 ppm sedangkan konsentrasi IBA yang digunakan yaitu 1 ppm dan 2 ppm. Selanjutnya dilakukan subkultur dengan menggunakan IBA dan BAP dengan kombinasi 0 ppm, 0,5 ppm, 0,75 ppm dan BAP 0 ppm, 0,5 ppm, 0,75 ppm. Hasil penelitian menunjukkan bahwa tunas paling banyak pada perlakuan kombinasi BA 2 ppm dan IBA 1 ppm sedangkan tinggi tunas dan jumlah daun paling baik dihasilkan perlakuan BA 1 ppm dan IBA 2 ppm serta jumlah tunas paling banyak ditunjukkan oleh perlakuan BA 2 ppm dan IBA 1 ppm. Penelitian ini dapat menyimpulkan bahwa perlakuan ZPT paling tepat untuk pertumbuhan tunas E. purpurea adalah BA 1 ppm dan IBA 2 ppm dan BA 2 ppm dan IBA 1 ppm. Sementara, pertumbuhan akar terbaik dihasilkan oleh kontrol.

Kata Kunci: Echinacea purpurea, Benzyl Adenin, Indole Butyric Acid, Kalus

\section{INTRODUCTION}

Echinacea (Echinacea purpurea (L.) Moench) is one of the medicinal plants widely used in the pharmaceutical industry. Echinacea is an introduced crop originating from America. This plant which is a member of the Asteraceae family. The plant is used extensively as a raw material by the pharmaceutical industry in Indonesia and is produced in the form of drugs, multivitamins, and energy drinks. The active ingredient in Echinacea consists of alkylamide, polyacetylene, caffeine acid esters, cichoric acid, polysaccharides and flavonoids such as kaempferol, quercetin, and isorhamnetin. Echinacea also contains several types of phenolic acids such as $\mathrm{p}$-kumarat, $\mathrm{p}$-hydroxybenzoate and $\mathrm{p}$ - protocatechuic (Kumar \& Ramaiah, 2011; Manayi, et al., 2015). Almost all parts of Echinacea have medicinal properties, some of which are as immune enhancers, and to treat respiratory infections, urinary tract infections, colds, and arthritis (Alamgir and Uddin, 2010; Hudson, 2012). Recently, the research has been conducted on the possibility of Echinacea as an HIV therapy material. Several HIV patients choose to use Echinacea as the herbal remedy due to its immunostimulatory properties as hypothesized in various studies (Moltó et al., 2012). The need of Echinacea plants is estimated will continue to increase each year. However, Echinacea in Indonesia is still imported. To obtain the medi- 
cine raw materials, domestic production in Indonesia is necessary. Indonesian Minister of Health Regulation No. 88 of 2013 concerning the master plan for the development of pharmaceutical raw materials, it is stated that to produce raw materials for traditional medicines in order to meet the needs of domestic raw materials guaranteed in high quality, it is necessary to increase the development and production of traditional pharmaceutical raw materials in the country and reduce the number of imports (Menkes, 2013). Thus, Indonesia can be independent of pharmaceutical raw materials and not depend on other countries.

Echinacea plants can grow well at an altitude of 450-1,100 $\mathrm{m}$ asl with a soil $\mathrm{pH}$ of 5.5 - 7.5. Echinacea cultivation requires full sun with loose soil and enough water (Raharjo, 2005). Echinacea is widely cultivated using seeds. However, the use of seeds has several obstacles, such as seeds provide a variety of germination responses, seeds collected from various regions require special treatment for the maintenance, seeds availability depend on the season, and the resulting plants from seeds are not free from pathogens (Abbasi et al., 2007). According to Raharjo (2005) plant death is caused by a virus attack or root rot due to root fungus. Therefore, it is necessary to propagate through tissue culture, instead of using seeds so the explant growth is not season-dependent and is pathogen free.

This study uses a Plant Growth Regulator (PGR) that consists of Benzyl Adenine (BA) and Indole Butyric Acid (IBA). PGR is an organic compound instead of nutrient which in the low concentration can give effect on the plant growth and development (Hariadi et al. 2019). According to Niedz and Evens (2011) BA is one type of cytokinin hormone that plays a role in stem organogenesis. Whereas according to Sidhu (2010) cytokinins plays a role in cell division, shoot induction and cell proliferation. In this study the hormone is combined with
IBA, which is a type of auxin hormone. According to Sidhu (2010) auxin plays a role in cell division, cell elongation and root differentiation. This study aims to determine the effect of BA and IBA on the growth of E. purpurea shoots and knowing the concentration of PGR which most influences the growth of the plant. BA is one type of cytokinin that has a strong and effective activity to stimulate the multiplication of shoots because it has a benzyl group while IBA at low concentrations can produce root growth (Lestari 2011). Research conducted by Mechanda, Baum, and Johnson (2003) produced shoot growth of $53.3 \%$ while the research conducted by Yusnita et al. (2013) applied BA 5 ppm and IBA 2000 ppm with Sansivera (Sansevieria trifasciata) explants for 3 months resulting in shoots 3.5 stems in 3 months and 19,7 roots in 2 months. Based on these studies it can be seen that BA is a PGR that produces shoot growth of shoots growth better than other PGR types of cytokines such as kinetin. BA is important tested on Echinacea because other PGRs have not been able to produce shoots of Echinacea. In the study conducted by Sudrajad and Saryanto (2011) using Ekinase leaf as explant with single PGR consist of BA 1,2,3 and $4 \mathrm{mg} / \mathrm{l}$ produced callus growth without shoots. Therefore it is needed research of BA combination with auxin for shoot growth.

\section{MATERIALS AND METHODS}

The study was conducted at the Center for Research and Development of Medicinal Plants and Traditional Medicines in June 2017.

\section{Experimental Design}

This study applied a completely randomized design (CRD) with test parameters including the number of callus, number of shoots, number of leaves, and number of roots. In this study two stages of research were carried out, namely shoot growth 
and root growth. The treatments used for shoot growth were a combination of $1 \mathrm{ppm}, 2 \mathrm{ppm}, 3$ ppm, and 4 ppm BA with a combination of $1 \mathrm{ppm}$ and 2 ppm IBA for shoot growth media. The treatments for root growth were PGR combination of $0.25 \mathrm{ppm}, 0.5 \mathrm{ppm}, 0.75 \mathrm{ppm}$ and $1 \mathrm{ppm}$ BAP and $0.25 \mathrm{ppm}, 0.5 \mathrm{ppm}, 0.75 \mathrm{ppm}$ and $1 \mathrm{ppm}$ IBA. This study used 3 replications for each treatment and no single ZPT treatment was used because the study only observed the effect of PGR combinations to obtain the best combination.

\section{Stock Solution Making}

The stock solutions consist of macronutrient, micronutrients, iron, myoinositol, and vitamins. Each macronutrient stock consisted of $\mathrm{NH}_{4} \mathrm{NO}_{3}$ $16.5 \mathrm{~g}, \mathrm{KNO}_{3} 19 \mathrm{~g}, \mathrm{CaCl}_{2} .2 \mathrm{H}_{2} \mathrm{O} 4.4 \mathrm{~g}, \mathrm{MgSO}_{4} .7 \mathrm{H}_{2} \mathrm{O}$ $3.7 \mathrm{~g}$, and $\mathrm{KH}_{2} \mathrm{PO}_{4} 1.7 \mathrm{~g}$. The reagent used is the Merck brand. Each reagent was dissolved in $10 \mathrm{ml}$ of sterile distilled water and stirred using the IKA C-Mag HS brand stirrer 7. Micronutrient stock consisted of $\mathrm{H}_{3} \mathrm{BO}_{3} 0.062 \mathrm{~g}, \mathrm{MnSO}_{4} \cdot 4 \mathrm{H}_{2} \mathrm{O} 0.223$ g, $\mathrm{ZnSO}_{4} .7 \mathrm{H}_{2} \mathrm{O} 0.086 \mathrm{~g}, \mathrm{NaMoO}_{4} .2 \mathrm{H}_{2} \mathrm{O} 0.00025$ g, $\mathrm{CuSO}_{4} \cdot 5 \mathrm{H}_{2} \mathrm{O} 0.00025 \mathrm{~g}, \mathrm{CoCl}_{2} \cdot 6 \mathrm{H}_{2} \mathrm{O} 0.00025$ $\mathrm{g}$ and $\mathrm{Kl} 0.0083 \mathrm{~g}$ dissolved in $100 \mathrm{ml}$ sterile distilled water. Iron stock consists of $\mathrm{FeSO}_{4} \cdot 7 \mathrm{H}_{2} \mathrm{O}$ $0.270 \mathrm{~g}, \mathrm{Na}_{2}$ EDTA.2 $\mathrm{H}_{2} \mathrm{O} .0 .373 \mathrm{~g}$ which is dissolved in sterile distilled water. The myoinositol stock solution was made by dissolving $100 \mathrm{ml}$ of sterile distilled water. The vitamin stock consists of nicotinic acid $0.005 \mathrm{~g}$, pirodoxin $\mathrm{HCl} 0.005 \mathrm{~g}$, Thiamin $\mathrm{HCl} 0.001 \mathrm{~g}$, and Glisine $0.02 \mathrm{~g}$ dissolved in $100 \mathrm{ml}$ sterile distilled water. The PGR used is the Merck brand. The PGR stock solution was made by dissolving $0.1 \mathrm{mg}$ of PGR with $100 \mathrm{ml}$ of sterile distilled water then stirred using a stirrer.

\section{Culture Media}

Culture media was made by mixing a stock solution of $10 \mathrm{ml}$ with $30 \mathrm{~g}$ of sucrose, $0.01 \mathrm{~g}$ of PVP and $7.5 \mathrm{~g}$ of gelatine. Then the culture media was added with 1 liter of distilled water and heated using a hotplate and stirred using a stirrer. The $\mathrm{pH}$ of the culture medium was adjusted to 5.6 by adding $\mathrm{NaOH}$ to reduce acidity or adding $\mathrm{HCl}$ to increase acidity. Then the ZPT was added to the concentration that was previously determined. The culture media was sterilized in Autoclave brand of Hirayama HL-AE series Vertical Autoclave for 30 minutes at $121^{\circ} \mathrm{C}$ and $1 \mathrm{~atm}$ pressure.

\section{Explant Selection}

The explants used were echinace leaves obtained from the greenhouse of the Center for Research and Development of Medicinal Plants and Traditional Medicine. The conditions for selecting explants are leaves that are young, growing healthy, free of pests and diseases.

\section{Explant Sterilization}

Echinace leaf was soaked in detergent for 3 minutes and rinsed three times using distilled water. The rinsed leaves were soaked in $0.5 \mathrm{~g}$ bactericide solution and rinsed three times using distilled water. The leaves soaked in $0.5 \mathrm{~g}$ fungicide and rinsed three times using distilled water. Then rinsed with distilled water three times and the explants were moved into Laminar Air Flow (LAF) ESCO brand Airstream vertical laminar Flow Clean Benches LVG. In LAF sterilization was soaked in $70 \%$ alcohol for 7 minutes then rinsed 3 times with distilled water. The explants soaked in 20\% sodium hypochlorite for 15 minutes and rinsed. The explants soaked into 20\% tween for 2 drops for 3 minutes and refracting. After sterile explants are ready to be planted.

\section{Explant Transferring}

Explants were cut into small pieces using a scalpel and then passed over the bunsen flame. Then the explants were transferred into a bottle that has been filled with culture media. 


\section{Incubation}

The explants were incubated for 1 month in an incubation room with a temperature of $23^{\circ} \mathrm{C}$ and light for 24 hours. During incubation, observation of growth were carried out. The parameters used included growing time, number of shoots, number of leaves, plant height, callus color, number of callus, and number of roots.

\section{Subculture}

After incubation for 1 month, then subcultures were carried out with MS base media and ZPT combination in the form of IBA and BAP.

\section{Data Analysis}

All variables were tested statistically using the Analyze of Variant and if there were real or very real differences, it would be continued with the Duncan difference test at the 5\% level.

\section{RESULTS AND DISCUSSION}

The results showed that BA 2 ppm + IBA 1 ppm treatment produced the fastest growth of callus for 8 days. Research conducted by Sudrajad and Saryanto (2011) using BAP can produce faster callus growth in an average of 5-7 days but no shoot growth occurs. At a lower concentration of BA, the results of long growth were 12.3 days while that of the highest BA treatment obtained callus growth at 10.33 days. Meanwhile, according to statistical tests, there was a significant difference between the growth of callus given the treatment of BA and IBA with controls (Table 1).

The combination treatment of BA $2+$ IBA 1 produces the fastest callus growth. The combination PGR of BA2 + IBA1 is the most appropriate combination so that it gives the fastest growth result. In the low concentration BA, callus growth rapidly while in the high concentration callus grows slowly. Slow growth can be caused by excessive PGR concentrations that inhibit explant growth. According to Agustina (2015) at low concentrations, PGR
Table 1. Growth of Echinacea purpurea (L.) Moench Callus with the combination of BA and IBA

\begin{tabular}{lrcc}
\hline Treatment & \multicolumn{3}{c}{ Growing time (in days) } \\
\hline $\mathrm{BA0}+\mathrm{IBA0}$ & - & \pm & 0.00 \\
$\mathrm{BA} 1+\mathrm{BBA} 1$ & 12.3 & \pm & 0.00 \\
$\mathrm{BA} 1+\mathrm{IBA} 2$ & 9.67 & \pm & 2.52 \\
$\mathrm{BA} 2+\mathrm{IBA} 1$ & 8 & \pm & 2.08 \\
$\mathrm{BA} 2+\mathrm{IBA} 2$ & 10 & \pm & 2.00 \\
$\mathrm{BA3}+\mathrm{IBA} 1$ & 11 & \pm & 2.00 \\
$\mathrm{BA} 3+\mathrm{IBA} 2$ & 13.66 & \pm & 2.65 \\
$\mathrm{BA4}+\mathrm{IBA} 1$ & 13.33 & \pm & 2.52 \\
$\mathrm{BA} 4+\mathrm{IBA} 2$ & 10.33 & \pm & 2.52 \\
\hline
\end{tabular}

can encourage growth, but at high concentrations, ZPT can inhibit growth and even cause death in plants.

Callus can form due to plant response to a wound. Callus formation comes from various types of cells that growth is stimulated by growth regulators and in subsequent growth can result in the formation of new organs or tissues (Ikeuchi et al., 2013). Callus initiation begins with the growth of parenchymal cells in the form of protuberances found in the epidermis or the bottom of the explant that is wounded. The bulge causes swelling of the tissue around the wound and grows into the middle of the explant. Furthermore, the tissue expands and the number is increasing (Hidayat 2007),

The results showed that callus was abundant in almost all treatments (Figure 1). Callus in small amounts was found in the treatment of BA1 + IBA1, BA2 + IBA2, and BA4 + IBA1. All the calluses were dark green (Table 2). Green callus arises from interactions between cytokinins and auxins that play a role in the formation of chlorophyll. Green callus shows that the callus contains a lot of chlorophyll while the white callus shows that the callus has begun to degrade chlorophyll but its growth is still good. A brown callus indicates that the cell has been physiologically degraded due to a lack of nutrients or growth hormones (Darmawati et al., 2013; Mahadi et al., 2013) 
The highest number of shoots was found in the BA2 + IBA1 treatment while the least number was in the control treatment and BA 4+ IBA 1 with no shoot growth (Table 2). BA and IBA at high concentrations gave quite good results, with 2.67 buds while at low concentrations produced 1.67 buds. In the treatment of BA $4+$ IBA 1 produced callus growth without shoot growth and slow callus growth. It is thought that this was caused by a combination of ZPT which was not appropriate for callus growth. According to Indah and Ermavitalini (2013) the slow formation of callus is due to inappropriate ZPT administration so that the endogenous and exogenous hormones present in the explants cannot stimulate callus growth quickly. High concentration cytokinin in BA4+IBA1 resulted in no shoot grow. The supraoptimal concentration of cytokinins causes the plant not to be affected or can be damaged. This is due to the use of PGR more than optimal concentrations of both cytokines and auxins that will inhibit growth (Dinarti et al., 2010; Rosmaina dan Aryani, 2015; Sukmadjaja dan Mulyana, 2011). According to statistical tests, there is a significant difference between the number of shoots that are given the treatment of BA and IBA with controls.

The plants that had the highest shoot were the BA1 + IBA2 treatment with a height of $1.56 \mathrm{~cm}$

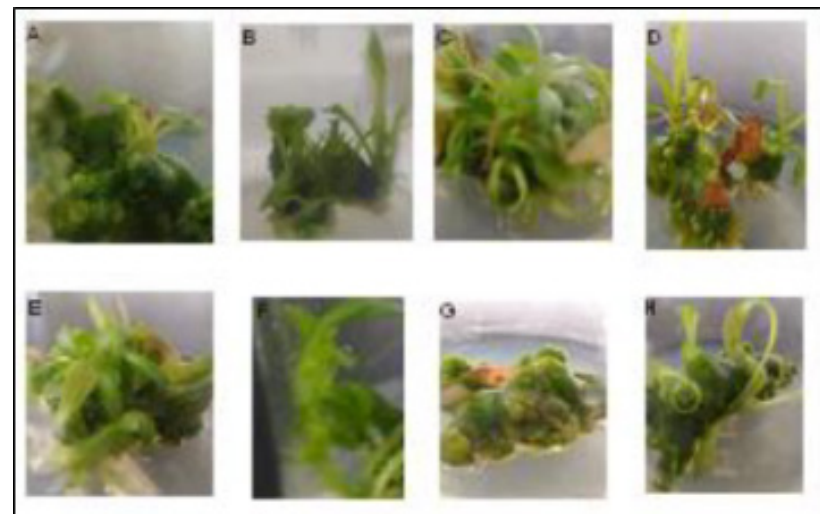

Figure 1. Results of shoot growth with BA and IBA treatment after 1 month. Results of Growth of Buds with BA and IBA treatment after 1 month with treatment a) $B A 1+\mid B A 1$ b) $B A 1+I B A 2 C) B A 2+I B A 1$ d) $B A 2+$ IBA2 e) $B A 3+$ IBA1 f) $B A 3+$ IBA2 g) $B A 4+$ IBA1 h) $\mathrm{BA} 4+\mathrm{IBA} 2$

while the lowest was found in the BA1 + IBA1 treatment with a height of $0,45 \mathrm{~cm}$.. The results of shoot growth between BA with high concentrations and low concentrations did not differ so much. At the lowest BA and IBA concentrations obtained $0.45 \mathrm{~cm}$ height while at BA and IBA concentrations obtained a height of $0.67 \mathrm{~cm}$. The high concentrations of IBA result in higher shoot sizes. Elongation of stems caused by division, elongation, and enlargement of cells in the apical meristem and stem segments so that plants grow taller (Widyastoety 2014). Auxin concentration gives effect to cell elongation. This hormone can stimulate protein synthesis and increase cell wall permeability,

Table 2. Shoot and Callus Growth of Echinacea purpurea (L.) Moench with a combination of BA and IBA after 1 month

\begin{tabular}{lrrrll}
\hline Treatment & Number of shoot (shoot) & Plant height $(\mathrm{cm})$ & Number of callus & Callus collor \\
\hline $\mathrm{BA0}+\mathrm{IBA0}$ & $0 \pm 0,00$ & $0 \pm 0,00$ & 0 & - \\
$\mathrm{BA} 1+\mathrm{IBA} 1$ & $1.67 \pm 0.58$ & $0.45 \pm 0.05$ & ++ & Dark green \\
$\mathrm{BA} 1+\mathrm{IBA} 2$ & $3.33 \pm 2.08$ & $1.56 \pm 0.14$ & +++ & Dark green \\
$\mathrm{BA2}+\mathrm{IBA} 1$ & $4.67 \pm 0.58$ & $0.8 \pm 0.61$ & ++ & Dark green \\
$\mathrm{BA2}+\mathrm{IBA} 2$ & $3.33 \pm 1.15$ & $1.36 \pm 0.2$ & +++ & Dark green \\
$\mathrm{BA3}+\mathrm{IBA} 1$ & $1.6 \pm 0.58$ & $0.8 \pm 0.9$ & +++ & Dark green \\
$\mathrm{BA3}+\mathrm{IBA} 2$ & $2 \pm 1.00$ & $0.6 \pm 0.08$ & +++ & Dark green \\
$\mathrm{BA4}+\mathrm{IBA} 1$ & $0 \pm 0.00$ & $0 \pm 0.00$ & ++ & Dark green \\
$\mathrm{BA4}+\mathrm{IBA} 2$ & $2.67 \pm 1.53$ & $0.67 \pm 0.31$ & +++ & Dark green \\
\hline
\end{tabular}

Remarks: + Little

++ Medium

+++ Much 
stimulate cell division and cell elongation so that it affects plant height. Stem elongation occurs due to division, elongation, and enlargement of new cells that occur in the apical meristem and stem segments so that plants grow tall (Rout et al., 2006; Santosa dan Soekendarsi, 2018). The BA1 + IBA1 treatment produces the smallest shoots. PGR concentration may be too low. According to statistical tests, there is a significant difference between the height of plants given the treatment and controls. The highest number of shoots was found in the BA2 + IBA2 treatment with 4.67 shoots. It is estimated that the treatment of BA $2+$ IBA 2 is the optimal concentration for bud formation. The results showed that the increasing concentration of cytokinins, the number of shoot growth decreased. These results are consistent with research conducted by Tajuddin, et al., (2015) using sago explants with the addition of NAA and BAP. In the study, the increase in BAP resulted in a drastic reduction in the number of shots while at lower concentrations the percentage of shoots was higher. According to Menurut Moore (1997) dan Wattimena (1988) in Rahmi et al., (2010) PGR with high concentrations does not help growth but inhibits growth because there is no balance of exogenous growth regulators and endogenous hormones present in explants so cell division is inhibited. The process depends on the ability of explants to receive exogenous ZPT.

The highest number of leaves was found in the BA1 + IBA2 while the least amount was in the BA3 + IBA1 and BA4 + IBA2 (Table 3). BA at the highest and lowest concentrations did not show results that differed greatly. In the treatment of BA1 + IBA1, the number of leaves was 7.33 strands, while in BA4 + IBA2, the number of leaves was 6 strands. In the BA4 + IBA1 treatment, only callus growth and no shoot growth occurred. Whereas the control did not occur in any growth. The results of shoot growth can be seen in Table 2 .
Table 3. Growth Echinacea purpurea (L.) Moench Leaves with Combination of BA and IBA

\begin{tabular}{lrcc}
\hline Treatment & \multicolumn{3}{c}{ Number of leaves } \\
\hline BA0 + IBA0 & 0 & \pm & 0.00 \\
BA1 + IBA1 & 7.33 & \pm & 3.06 \\
$B A 1+I B A 2$ & 10.67 & \pm & 7.51 \\
$B A 2+$ IBA 1 & 9 & \pm & 5.57 \\
$B A 2+$ IBA 2 & 6.3 & \pm & 2.31 \\
BA3 + IBA 1 & 6 & \pm & 5.29 \\
BA3 + IBA 2 & 8.33 & \pm & 7.57 \\
BA4 + IBA 1 & 0 & \pm & 0.00 \\
BA 4+IBA 2 & 10.33 & \pm & 2.52 \\
\hline
\end{tabular}

The highest number of leaves was found in the BA1 + IBA2 treatment with an average number of leaves of 10.67 strands. Auxin and cytokines in the right amount can increase cell division to form plant organs (Rahayu, Solichatun, and Endang 2003). According to statistical tests, there was no significant difference between the number of leaves given the treatment and controls.

After the emergence of shoot growth subcultures were carried out into BAP and IBA media to obtain shoot and root growth. According to research conducted by Salim et al., (2010), IBA can increase the number of secondary roots, root length, stimulate root formation and enlargement. The subculture with BAP and IBA treatments resulted in root growth only in the control treatment with 6.67 strands (Figure 2) while other treatments did not produce root growth. According to statistical tests, there is a significant difference between the number of roots given in the treatment of BA and

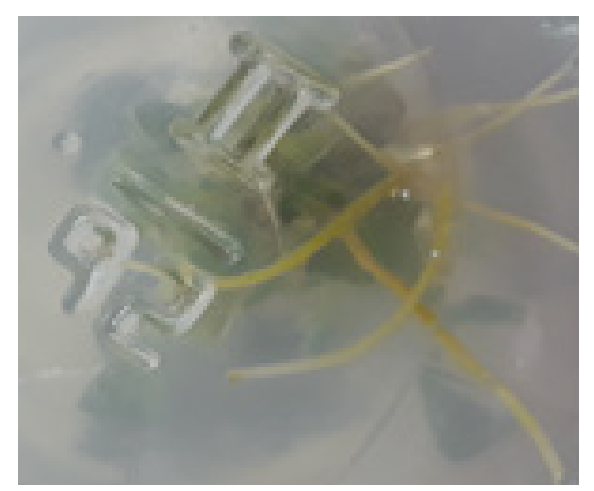

Figure 2. Root Growth after 1 Month in the Control Treatment 
Table 4. Root Growth with IBA and BAP treatment after 1 month

\begin{tabular}{|c|c|c|c|}
\hline \multirow{2}{*}{$\begin{array}{l}\text { Treatment } \\
\mathrm{BA} 0+\mathrm{IBA} 0\end{array}$} & \multicolumn{3}{|c|}{ Number of roots (sheets) } \\
\hline & 6.67 & \pm & 1.53 \\
\hline $\mathrm{BA} 1+\mathrm{BA} 1$ & 0 & \pm & 0.00 \\
\hline $\mathrm{BA} 1+\mathrm{BA} 2$ & 0 & \pm & 0.00 \\
\hline $\mathrm{BA} 2+\mathrm{IBA} 1$ & 0 & \pm & 0.00 \\
\hline $\mathrm{BA} 2+\mathrm{IBA} 2$ & 0 & \pm & 0.00 \\
\hline $\mathrm{BA} 3+\mathrm{IBA} 1$ & 0 & \pm & 0.00 \\
\hline $\mathrm{BA} 3+\mathrm{IBA} 2$ & 0 & \pm & 0.00 \\
\hline $\mathrm{BA} 4+\mathrm{IBA} 1$ & 0 & \pm & 0.00 \\
\hline $\mathrm{BA} 4+\mathrm{IBA} 2$ & 0 & \pm & 0.00 \\
\hline
\end{tabular}

IBA with controls. The results of the subculture are shown in Table 4.

Treatment without PGR (control) resulting in root growth. It caused by explants in the control that have high endogenous hormones and are sufficient for root growth without the need for additional growth regulators in culture media. According to Sulichantini (2016) explants can have a meristem tissue that is actively dividing and rich in endogenous growth-regulating substances so that it can trigger growth without the need for exogenous PGR.

Auxin can influence the root cell elongation process by initiating cell elongation. This hormone affects the flexing of the cell wall. Auxin affects the $\mathrm{H}+$ ion pump to the cell wall by stimulating certain proteins in the plasma membrane. The $\mathrm{H}^{+}$ ion activates certain enzymes so that the hydrogen crosslinking that arrange the cell wall breaks. Cells are getting longer due to water enters by osmosis. Cells continue to growth by synthesizing the constituent material of the cell wall and cytoplasm (Kusumo (1990) in Yuliawan (2019). Although able to increase the number of roots, auxin can also inhibit root growth if the concentration is excessive. Excess auxin is toxic to plants because it disturbs the plant's cell division process. Abundant nitrogen found in media combined with various PGRs, especially auxin, will form amino acids that inhibit root growth (Putra and Shofi 2015). Treatment with PGR in the culture media did not produce root growth because explants could not absorb nutrients in the culture media so that it grew stunted.

\section{CONCLUSION}

The conclusion is BA and IBA influences the growth of shoots of Echinacea purpurea (L.) Moench). The most appropriate PGR treatments for the growth of these plant shoots were BA1 ppm+IBA 2 ppm and BA 2 ppm+IBA 1 ppm, whereas for root growth control produced the best growth. Further research is needed regarding tissue culture of Echinacea along with levels of flavonoids in callus at various concentrations of growth regulators.

\section{ACKNOWLEDGEMENT}

This study was funded by the Center for Research and Development of Medicinal Plants and Traditional Medicines, Ministry of Health.

\section{REFERENCES}

Abbasi, B. H., Murch, S., \& Saxena, P. K. (2007). Echinacea biotechnology : Challenges and opportunities. In Vitro Cell.Dev.Biol.-Plant, 43, 481-492. https://doi.org/10.1007/s1 1627-007-9057-2

Agustina, L. . (2015). Pengaruh Konsentrasi Zat Pengatur Tumbuh Auksin Golongan NAA dan Waktu Penyiangan terhadap Pertumbuhan dan Hasil Kacang Hijau (Vigna radiata L.). Agroswagati, 13(2), 364-374.

Alamgir, M., \& Uddin, S. J. (2010). Recent Advances on The Ethnomedicinal Plants as Immunomodulatory Agents. Ethnomedicine: $A$ Source of Complementary Therapeutics, 37/661(2), 227-244. Darmawati, I. A. P., Dwiyani, R., \& Hestin, D. A. N. (2013). Induksi Kalus dengan 2,4-D pada Mikropropagasi Tanaman Stroberi ( Fragraria x ananassa Duch cv . Rosalinda ). Agrotrop, 3(2), 21-26.

Dinarti, D., Sayekti, U., \& Alitalia, Y. (2010). Kultur Jaringan Kantong Semar (Nepenthes mirabilis). J.Hort. Indonesia, 1(2), 59-65.

Hariadi, H., Yusnita, Riniarti, M., \& Hapsoro, D. (2019). Pengaruh Arang Aktif, Benziladenin, dan Kinetin terhadap Pertumbuhan Tunas Jati Solomon (Tectona grandis Linn. f) In Vitro. Jurnal Biologi Eksperimen Dan Keanekaragaman Hayati, 5(2), 21-30. Hidayat. (2007). Induksi Pertumbuhan Eksplan Endosperm Ulin dengan IAA dan Kinetine. Agritrop, 26(4), 147-152.

Hudson, J. B. (2012). Applications of the Phytomedicine Echinacea 
purpurea ( Purple Coneflower ) in Infectious Diseases. Journal of Biomedicine and Biotechnology, 2012, 1-16. https://doi. org/10.1155/2012/769896

Ikeuchi, M., Sugimoto, K., \& Iwase, A. (2013). Plant Callus : Mechanisms of Induction and Repression. The Plant Cell, 25, 31593173. https://doi.org/10.1105/tpc.113.116053

Indah, P. N., \& Ermavitalini, D. (2013). Induksi Kalus Daun Nyamplung (Calophyllum inophyllum Linn.) pada Beberapa Kombinasi Konsentrasi 6-Benzylaminopurine (BAP) dan 2,4-Dichlorophenoxyacetic Acid (2,4-D). Jurnal Sains dan Seni Pomits, 2(1), 1-6.

Kumar, K. ., \& Ramaiah, S. (2011). Pharmacological Importance of Echinacea purpurea. International Journal of Pharma and Bio Sciences, 2(2), 304-414.

Lestari, E. G. (2011). Peranan Zat Pengatur Tumbuh dalam Perbanyakan Tanaman melalui Kultur Jaringan. Agrobiogen, 7(1), 63-68.

Mahadi, I., Wulandari, S., \& Trisnawati, D. (2013). Pengaruh Pemberian NAA dan Kinetin Terhadap Pertumbuhan Eksplan Buah Naga (Hylocereus costaricensis) melalui Teknik Kultur Jaringan secara In Vitro. Jurnal Biogenesis, 9(2), 14-20. http://www. albayan.ae

Manayi, A., Vazirian, M., \& Saeidnia, S. (2015). Echinacea purpurea : Pharmacology, phytochemistry and analysis methods. Pharmacognosy Reviews, 9(17), 63-73. https://doi. org/10.4103/0973-7847.156353

Mechanda, S. M., Baum, B. R., \& Johnson, D. A. (2003). Direct Shoot Regeneration from Leaf Segments of Mature Plants of Echinacea purpurea ( L .) Moench. In Vitro Cell. Dev. Biol.-Plant, (October), 505-509. https://doi.org/10.1079/IVP2003461

Menkes. Peraturan Pemerintah Nomor 88 Tahun 2013 (2013).

Moltó, J., Valle, M., Miranda, C., Cedeño, S., Negredo, E., \& Clotet, B. (2012). Herb-Drug Interaction between Echinacea purpurea and Etravirine in HIV-Infected Patiens. Antimicrobial Agents and Chemotherapy, 56(10), 5328-5331. https://doi.org/10.1128/ AAC.01205-12

Niedz, R. P., \& Evens, T. J. (2011). The Effects of Benzil Adenine and Meta-topolin on In Vitro Shoot Regeneration of Sweet Orange. ARPN Journal of Agricultural and Biological Science, 6(3), 64-73.

Putra, R. R., \& Shofi, M. (2015). Pengaruh Hormon Napthalen Acetic Acid terhadap Inisiasi Akar Tanaman Kangkung Air ( Ipomoea aquatica Forssk .) Jurnal Wiyata, 2(2), 108-113.

Raharjo. (2005). Peluang Pembudidayaan Tanaman Echinacea (Echinacea purpurea) di Indonesia. Jurnal Prespektif, 4(1), 1-10.

Rahayu, B., Solichatun, \& Endang, A. (2003). Pembentukan dan Pertumbuhan Kalus serta Kandungan Flavonoid Kultur Kalus Acalipha indica. Biofarmasi, 1(1), 1-6.

Rahmi, I., Suliansyah, I., \& Bustamam, T. (2010). Pengaruh Pemberian Beberapa Konsentrasi BAP dan NAA terhadap Multiplikasi
Tunas Pucukjeruk Kanci ( Citrus Sp ) Secara In Vitro. Jerami, 3(3), 210-219.

Rosmaina, \& Aryani, D. (2015). Optimasi NAA dan BAP terhadap Pertumbuhan dan Perkembangan Tunas Mikro Tanaman Kantong Semar (Nepenthes mirabilis) Secara In Vitro. Jurnal Agroteknologi, 5(2), 29-36. https://doi.org/10.24014/ ja.v5i2.1352

Rout, G. R., Mohapatra, A., \& Jain, S. M. (2006). Tissue Culture of Ornamental Pot Plant : A Critical Review on Present Scenario and Future Prospects. Biotechnology Advances 24, 24, 531-560. https://doi.org/10.1016/j.biotechadv.2006.05.001

Salim, H., Myrna, N., \& Yulia, A. (2010). Pertumbuhan Bibit Manggis Asal Seedling(Garcinia Mangostana L.) Pada Berbagai Konsentrasi IBA. Jurnal Penelitian Universitas Jambi Seri Sains., 12(2007), 19-24.

Santosa, S., \& Soekendarsi, E. (2018). Utilization of Rice and Coconut Water Waste to Accelerate The Growth of Syzygium myrtifolium ( Roxb ) Walp Seedlings on Sediment Media. Academic Research International, 9(December), 1-5.

Sidhu, Y. (2010). In Vitro Micropropagation of Medicinal Plants by Tissue Culture. The Playmouth Student Scientist, 4(1), 432-449.

Sudrajad, H., \& Saryanto. (2011). Pengaruh Penambahan Sitokinin pada Senyawa Flavonoid Kalus ( Echinacea purpurea L ). Prosiding Seminar Nasional "Peranan dan Kontribusi Herbal dalam Terapi Penyakit Degeneratif .pp. 102-108.

Sukmadjaja, D., \& Mulyana, A. (2011). Regenerasi dan Pertumbuhan Beberapa Varietas Tebu ( Saccharum officinarum L .) secara In Vitro. Jurnal AgroBiogen, 7(2), 106-118.

Sulichantini, E. D. (2016). Pengaruh Konsentrasi Zat Pengatur Tumbuh Terhadap Regenerasi Bawang Putih ( Allium sativum L ). Jurnal Agrifor, 16(1), 29-36.

Tajuddin, T., Karyanti, Sukarnih, T., \& Haska, N. (2015). The Combination of Growth Hormones Increased The In Vitro Shoots Multiplication on Sago Palm ( Metroxylon Sagu Rottb.). Jurnal Bioteknologi dan Biosains Indonesia, 2(1), 27-33.

Widyastoety, D. (2014). Pengaruh Auksin dan Sitokinin terhadap Pertumbuhan Planlet Anggrek Mokara. Jurnal Hortikultura, 24(3), 230-238.

Yuliawan, W. (2019). Pertumbuhan Beberapa Bentuk Potongan Pangkal Setek Tanaman Mawar (Rosa sp.) Akibat Cara Aplikasi Zat Pengatur Tumbuh Root-Up. Jurnal Ilmiah Pertanian Paspalum, 7(1), 42-47.

Yusnita, Wahyuningsih, T., Sulistiana, P., \& Hapsoro, D. (2013). Perbanyakan In Vitro Sansevieria trifasciata ' Lorentii ': Regenerasi Tunas, Pengakaran, dan Aklimatisasi Planlet In Vitro Propagation of Sansevieria trifasciata ' Lorentii ': Shoot Regeneration , Rooting , and Plantlet Acclimatization. J. Agron. Indonesia, 41(1), 70-76. 